\title{
O zadawaniu pytań na lekcji języka polskiego Studium przypadku
}

\author{
On asking questions in the Polish language lesson \\ Case study
}

Summary: The article presents the results of qualitative and quantitative analysis of questions asked during a single Polish language lesson. It consists of two main parts. The first presents and comments on the results of the teacher's questions analysis, the second - questions asked by students. The concept of Bogusław Skowronek was used, who distinguished four types of questions in his classification: 1) reassuring-instrumental; 2) substantive; 3) about the meta-didactic function; 4) not related to the classroom situation. The first two categories were specified in more detail by Elizabeth Perrott's proposition, which distinguishes between guiding questions and questions for clarification among reassuring-instrumental questions, while she divides substantive questions according to the type of thought process launched during the answer and indicates lower-order and higher-order questions. The text ends with a summary containing not very optimistic conclusions.

Keywords: lesson dialogue, conversation, question, teacher, student

\section{Wprowadzenie}

W tradycji kształcenia polonistycznego, odwołującej się między innymi do szkoły sokratycznej, rozmowa jest jednym z najistotniejszych działań dydaktycznych. Jak zauważa Barbara Myrdzik, na rozmowę można spojrzeć trojako: a) jako na „ideę wychowania”, w której respektuje się podmiotowość nauczyciela i ucznia; b) jako na koncepcję kształcenia kulturowo-literackiego, traktującą 
tekst literacki jako medium porozumiewania między odbiorcami, i wreszcie jako c) na metodę nauczania - uczenia się. „Dialog z tekstami kultury odbywa się w trakcie rozmowy na ich temat, rozmowa staje się również metodą nauczania - uczenia się"1. Zdaniem przywołanej badaczki, prowadzenie rozmowy wymaga od jej partnerów, by mieli zarysowany kierunek i cel; upewniali się, czy partner nadąża; podporządkowali się sprawie, na której skupiają uwagę; nie dążyli do przekonania w rozmowie za wszelką cenę, ale uwzględnili rzeczowość odmiennego poglądu; umieli stworzyć atmosferę sprzyjającą wymianie myśli, opanowali nie tylko umiejętność logicznego argumentowania, lecz także uważnego słuchania i milczenia ${ }^{2}$.

Jedną z możliwości opisu rozmowy w perspektywie edukacyjnej (w tym aksjologicznej i komunikacyjnej) jest analiza pytań. Mieszczą się tu takie szczegółowe kwestie, jak: kto i w jakim celu inicjuje rozmowę, jakie są proporcje uczestnictwa nauczyciela i ucznia w dialogu, jaki rodzaj pytań pojawia się najczęściej w dyskursie lekcyjnym czy wreszcie jakiego poziomu myślenia kognitywnego wymagają stawiane pytania. W artykule przedstawiam wyniki jakościowej i ilościowej analizy pytań zadawanych podczas lekcji z języka polskiego na temat: Konstrukcja fabuly ,Matego Księcia” i jej znaczenie, przeprowadzonej w I klasie gimnazjum ${ }^{3}$. Wybierając materiał ${ }^{4}$, założyłam, że analizowany przypadek jest ilustracją istotnego problemu i ,ułatwia zrozumienie czegoś poza nim samym"s.

Zdaniem Bogusławy D. Gołębniak, „źródłem intelektualnego wyzwania w znaczeniu zachęcania do werbalizowania tego, co uczeń już wie na dany te-

${ }^{1}$ B. Myrdzik: Czy rozmowa jest metodą?. W: Eadem: Nowoczesność i tradycja w ksztatceniu literackim. Podręcznik do ćwiczeń z metodyki języka polskiego. Lublin 2000, s. 99.

${ }^{2}$ Ibidem, s. 100-101.

3 Nagranie udostępnione przez Instytut Badań Edukacyjnych.

${ }^{4} \mathrm{Na}$ znaczącą rolę pytań w komunikacji dydaktycznej zwraca uwagę wielu badaczy, między innymi E. Biłos (1992), M. Kawka (1999), W. Kojs (1975, 1994), S. Mieszalski (1990), J. Nocoń (1997), E. Nowak (2005), E. Putkiewicz (1990), B. Skowronek (1999).

5 W klasyfikacji opracowanej przez R. Stake'a wyróżnione zostały trzy rodzaje studium przypadku: autoteliczne, instrumentalne i zbiorowe. Autoteliczne studium przypadku podejmuje się w celu dogłębnego poznania konkretnego przypadku. Wybiera się dany przypadek, bo jest on ciekawy sam w sobie. W instrumentalnym studium przypadku sam przypadek ma rolę pomocniczą - dobiera go się dlatego, że jest ilustracją jakiegoś ważnego, z punktu widzenia badacza, problemu. W zbiorowym (wielokrotnym) studium przypadku — po to, by jeszcze lepiej niż w studium instrumentalnym zrozumieć badane zjawisko, analizuje się nie pojedynczy przypadek, lecz całą ich serię. Zob. R.E. Stake: Studium przypadku. W: Ewaluacja w edukacji. Red. L. Korporowicz. Warszawa, s. 123. Za H. Mizerek: Studium przypadku w badaniach nad edukacja. Istota i paleta zastosowań, s. 14. https://repozytorium.ukw.edu.pl/bitstream/handle/item/5517/ Studium $\% 20$ przypadku $\% 20$ w\%20badaniach $\% 20$ nad $\% 20$ edukacj $\%$ c4\%85\%20Istota $\% 20 i \% 20$ paleta\%20zastosowa\%c5\%84.pdf?sequence=1\&isAllowed=y [data dostępu: 15.03.2020]. W artykule przyjęłam określenie perspektywa instrumentalna. 
mat, a czego jeszcze chciałby się dowiedzieć [...], może być w praktyce szkolnej strategia stawiania pytań" ${ }^{\prime \prime}$. W dyskursie lekcyjnym ta koncepcja stymulowania rozwoju intelektualnego realizowana jest dwiema ścieżkami:

- kierowaniem pytań przez nauczycieli do uczniów;

— zachęcaniem uczniów do stawiania pytań.

Badaczka za dobre pytanie uznaje to, które jest „pomostem” między nauczaniem i uczeniem się:

Zamiast wielu drobiazgowych pytań (kto?, co?, kiedy?, gdzie?) warto formułować pytania otwarte, w sposób niewymuszający udzielania natychmiastowej odpowiedzi, ale zachęcający do zagłębiania problemu i własnego myślenia o nim $[\ldots]^{7}$.

W artykule nadrzędny podział pytań przyjmuję za Bogusławem Skowronkiem, który wyodrębnił następujące typy pytań funkcjonujących w dyskursie lekcyjnym:

— pytania merytoryczne — związane treściowo z tematem lekcji;

- pytania upewniająco-instrumentalne pełniące funkcje pomocnicze podczas lekcji, zwykle stawiane doraźnie w celu uściślenia, doprecyzowania informacji; pytający upewnia się co do kształtu i zawartości informacji już posiadanej;

- pytania o funkcji metadydaktycznej - dotyczące samego przebiegu lekcji, jej organizacji;

- pytania niezwiązane z lekcją ${ }^{8}$.

Wykres 1. przedstawia podział pytań ze względu na ich funkcję z uwzględnieniem ich liczby w analizowanym materiale.

Podczas analizowanej lekcji postawiono 114 pytań, z czego 109 zadała nauczycielka, a 5 - uczniowie. Spośród 109 pytań nauczycielki 56 miało charakter merytoryczny, 49 upewniająco-instrumentalny i 4 metadydaktyczny (pytania niezwiązane z lekcją nie padły ${ }^{9}$ ). Z kolei wśród 5 pytań uczniów 2 były merytoryczne, 1 upewniająco-instrumentalne, 2 realizowały funkcję metadydaktyczną.

W dalszej części przedstawiam wyniki szczegółowej analizy badanego materiału.

${ }^{6}$ B.D. Gołębniak: Nauczanie i uczenie się w klasie. W: Pedagogika 2. Podręcznik akademicki. Red Z. Kwieciński, B. Śliwerski. Warszawa 2014, s. 179.

${ }^{7}$ Ibidem.

${ }^{8}$ Zob. B. Skowronek: O dialogu na lekcjach w szkole średniej. Analiza pragmatyczno-językowa. Kraków 1999, s. 59-65.

9 Powodem braku pytań niezwiązanych z sytuacją lekcyjną mógł być fakt, że lekcja była rejestrowana. 


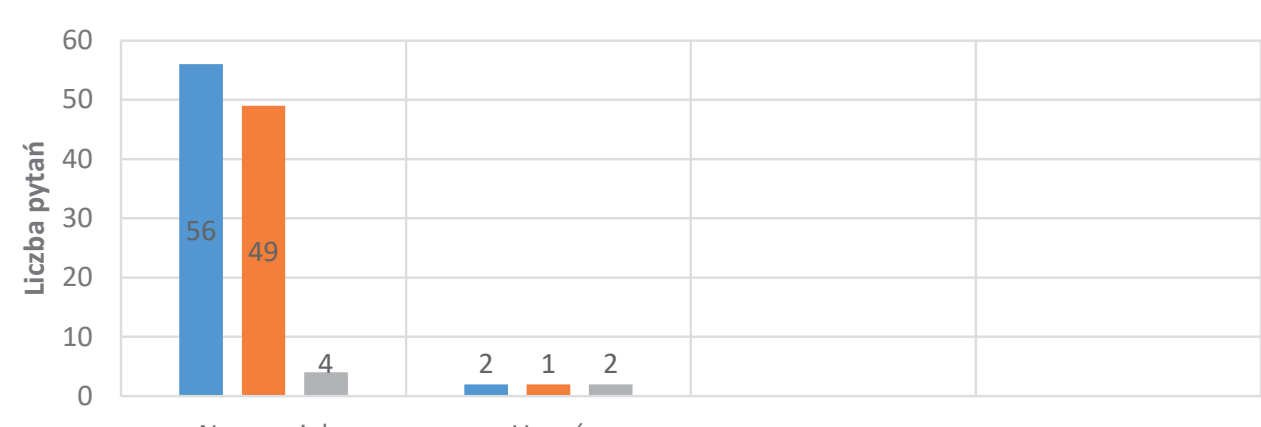

Typy pytań

- pytania merytoryczne $\square$ pytania upewniająco-instrumentalne $\square$ pytania metadydaktyczne

Wykres 1. Rozkład pytań ze względu na ich funkcję

Źródło: opracowanie własne.

\section{Nauczycielskie pytania merytoryczne}

Pytania merytoryczne treściowo związane są z tematem lekcji. Nadawca, zadając ten typ pytania, chce pozyskać nową informację. $\mathrm{Z}$ dydaktycznej perspektywy pytania merytoryczne są niezwykle istotne, ponieważ „budują poznawczo proces omawiania określonego tematu" ${ }^{\prime 10}$. Biorąc pod uwagę poziom myślenia kognitywnego, jakiego wymagają pytania, Elizabeth Perrott dzieli je na dwie zasadnicze grupy: pytania niższego rzędu oraz pytania wyższego rzędu. Pierwsza grupa obejmuje pytania typu: przypominanie, zrozumienie i zastosowanie, uruchamiające myślenie reproduktywne, z kolei w drugiej mieszczą się pytania analityczne, syntetyczne oraz ewaluacyjne, wymagające myślenia utożsamianego z rozwiązywaniem problemów ${ }^{11}$.

Warto zaznaczyć, że w dyskursie lekcyjnym zadawane powinny być zarówno pytania niższego poziomu, jak i pytania wyższego poziomu. Te pierwsze służą nauczycielowi w sprawdzaniu wiedzy ucznia oraz rozpoznawaniu ewentualnych braków, mają zatem charakter odtwórczy, a „Odpowiedź oparta na przypomnieniu nie wychodzi poza informacje uprzednio podane. [...] łatwo [je — A.T.] określić jako właściwe lub błędne"12. Z kolei pytania poziomu wyż-

${ }^{10}$ B. Skowronek: $O$ dialogu..., s. 61.

${ }^{11}$ Zob. E. Perrott: Pytania. W: Eadem: Efektywne nauczanie. Praktyczny przewodnik doskonalenia nauczyciela. Tłum. A. Janowski. Warszawa 1995, s. 50.

${ }^{12}$ Ibidem. 
szego aktywizują ucznia, pobudzają do dyskusji, rozmowy, umożliwiają szukanie własnych rozwiązań postawionego w pytaniu problemu, mają charakter twórczy. „Aby odpowiedzieć na pytanie wyższego rzędu, uczeń może przypomnieć sobie lub otrzymać informacje, ale musi wyjść poza nie i [je - A.T.] przetworzyć [...]"13. W analizowanym materiale nauczycielka zadawała pytania uruchamiające myślenie zarówno niższego, jak i wyższego rzędu. Wykres 2. przedstawia stosunek liczbowy obu kategorii pytań.

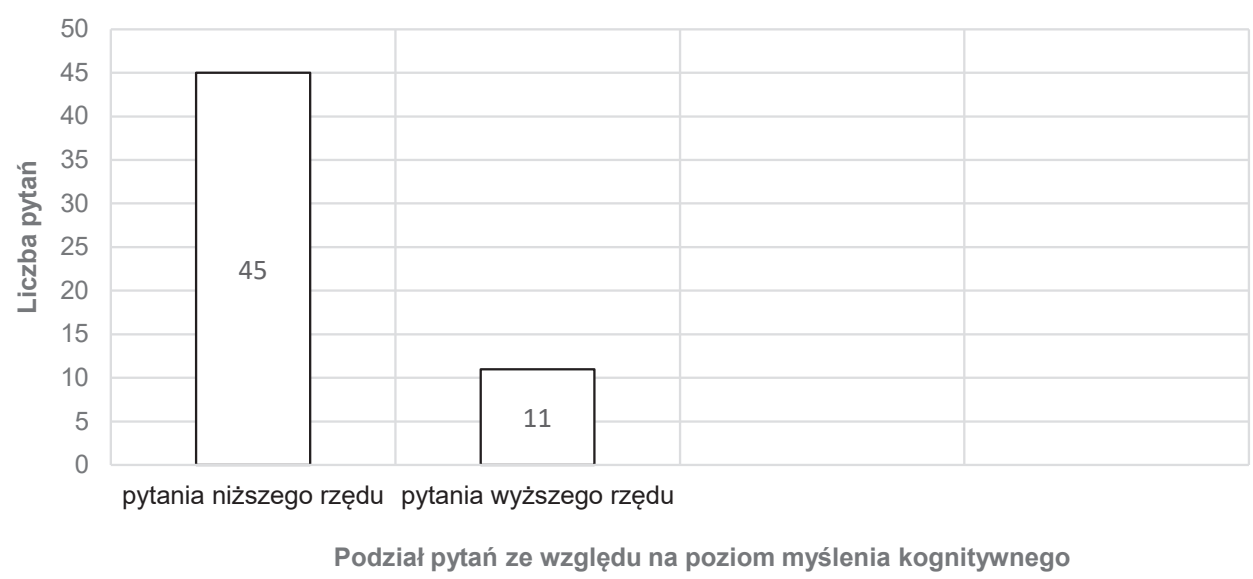

Wykres 2. Stosunek liczby pytań niższego rzędu do liczby pytań wyższego rzędu Źródło: opracowanie własne.

Z wykresu 2. wynika, że ponad $80 \%$ pytań, jakie zadała polonistka, to pytania uruchamiające myślenie reproduktywne. Wśród nich najwięcej dotyczyło przypomnienia informacji (40 pytań). Przykładowo ${ }^{14}$ :

$\mathrm{N}$ : Co to jest fabuła?

U: Różne wątki dotyczące książki.

$\mathrm{N}$ : Co sktada się na świat przedstawiony?

$\mathrm{U}$ : Wszystko opisane w książe.

$\mathrm{N}$ : Jak nazwiemy ten moment narracji, rozwoju akcji?

$\mathrm{U}$ : Zawiazanie?

$\mathrm{N}$ : Jak nazwiemy narracje??

U: Trzecioosobowa.

$\mathrm{N}$ : Jakie kryteria musi spetnić baśń?

U: Szczęśliwe zakończenie.

${ }^{13}$ Ibidem.

${ }^{14}$ Transkrypcję lekcji wykonała Aleksandra Lipieta. W cytatach zachowano oryginalną pisownię, a wyróżnienia (czcionką półgrubą) pochodzą od autorki opracowania. 
Tak sformułowane pytania wymagają od ucznia podania zapamiętanych faktów, informacji bez konieczności ich przetwarzania. Nauczyciel, otrzymując informację zwrotną, czy uczeń wie, Co to jest fabuła, Co się sktada na świat przedstawiony itd., z łatwością może ocenić poprawność odpowiedzi. Mimo że wiedza jest podstawą wyższych poziomów myślenia (nie można oczekiwać od ucznia myślenia dywergencyjnego, jeżeli brakuje mu podstawowych informacji), to ta kategoria pytań niesie wiele niebezpieczeństw. Po pierwsze, nauczyciele mają tendencje do ich nadużywania ${ }^{15}$; po drugie, wiadomości, jakie odtwarza uczeń, niekoniecznie rozumie (może pamiętać, ale nie rozumieć); po trzecie, „poprzez pytania o wiedzę ocenia się tylko powierzchowne rozumienie zjawisk, a to, co zapamiętane, staje się w końcu szybko zapomniane"16, i wreszcie po czwarte, pytania tego typu nie wymagają dłuższej odpowiedzi ucznia, co ilustrują przywołane przykłady. Wypowiedzi zainicjowane przez nauczycielkę pytaniami sprawdzającymi wiedzę w dużej mierze mają charakter pojedynczych wypowiedzeń, ograniczających się do jednego, dwóch wyrazów.

Pozostałe pytania niższego poziomu to pytania o zrozumienie (7), np.:

N: ,, Maty Książe”, do czego odsyta nas tytut?

U: Do postaci.

\section{$\mathrm{N}:$ Jaki charakter miała ta podróż?}

$\mathrm{U}:$ Mmm... poznawczy.

$\mathrm{N}$ : Jaki wpływ maja miejsca, te... te badane?

$\mathrm{U}$ : Więc jest planeta Małego Księcia, na której jakby się wychowat, opowiadat, jakie czynności, miat on swoje zajęcia i obowiazki na tej planecie do wykonywania, pielęgnowanie róż, czyszczenie wulkanów, eee byty też...

Celem tej kategorii pytań jest pomoc uczniowi w operowaniu posiadaną wiedzą, uporządkowaniu przedstawianych faktów, które zawarł w swej wypowiedzi. Podobnie jednak jak poprzednie pytania, są tak skonstruowane, że nie wymagają od ucznia dłuższych wypowiedzi świadczących o umiejętności wyboru niezbędnych informacji czy ich przetransformowania.

Przywołując koncepcję Douglasa Barnesa ${ }^{17}$, kształt komunikacji między polonistą i uczniami można porównać do „wersji ostatecznej”. Podstawowym ce-

${ }^{15}$ Wskazują na to między innymi wyniki badań, które przeprowadziłam na podstawie analiz jakościowych i ilościowych pytań proponowanych w scenariuszach lekcji języka polskiego i zadawanych podczas ustnego egzaminu maturalnego z języka polskiego. Zob. A. Tabisz: O pytaniach... Ea dem: Czy lekcje języka polskiego uczq myślenia?. „Polonistyka. Innowacje” [w druku].

${ }^{16}$ E. Perrott: Pytania..., s. 45.

17 Zob. D. Barnes: Nauczyciel i uczniowie. Od porozumiewania się do ksztatcenia. Thum. J. Radzicki. Warszawa 1988. 
lem tego typu porozumiewania się, charakteryzującego się zrytualizowaniem, biernością ucznia, ograniczonością, jest pozyskanie akceptacji nauczyciela. Przywołane fragmenty dialogu są przykładem redukcyjno-instrumentalnego podejścia do rozwijania kompetencji mówienia, dla którego typowa jest „wybiórcza dominacja funkcji informacyjnej wypowiedzi ustnych z jednoczesną redukcją lub eliminacją pozostałych funkcji oraz sprowadzanie komunikacji do roli narzędzia przekazu i egzekwowania wiadomości szkolnych"18. Zgodzić się należy z Dorotą Klus-Stańską i Marzenną Nowicką, które twierdzą, że uczeń wciąż nie ma warunków, by rozwijać związane z mówieniem kompetencje, między innymi: słuchanie innych, nawiązanie do ich wypowiedzi; podtrzymywanie interakcji, polemizowanie; dobieranie trafnych argumentów i kontrargumentów; utrzymanie głównego wątku wypowiedzi; wzbudzanie zainteresowania słuchacza; korzystanie z języka pozawerbalnego; wyrażanie własnych uczuć, postaw, przeświadczeń; zwiększanie skuteczności osiągania celu mówienia; mówienie w zróżnicowanych sytuacjach i formach ${ }^{19}$. Skupienie uwagi na warstwie informacyjnej wypowiedzi powoduje, że rozmowa lekcyjna staje się pogadanką heurystyczną, podczas której uczeń jest pozbawiony możliwości rozwijania samodzielnych strategii myślenia ${ }^{20}$.

Samodzielnemu myśleniu sprzyjają pytania wyższego rzędu. W trakcie analizowanej lekcji padło 10 pytań tej kategorii, z czego 9 dotyczyło analizy, a 1 syntezy. Przykładowo:

$\mathrm{N}$ : A więc literatura ma tu swoje uprawnienia, że może ten świat zmienić?

$\mathrm{U}:$ Ja bym jednak zaliczyt te postacie na planetach do realistycznych, ale tak nie do końca, bo oni mieszkali w kosmosie, ale one mogły mieszkać na Ziemi i mogłyby tam żyć i być realistyczne.

$\mathrm{N}$ : Tak i historia Matego Księcia... dobrze. Bo pytanie jest, kto nam to wszystko opowiada, tak? Kto nam to wszystko opowiada?

U: Maty Ksiązę? Pilot!

N: Proszę bardzo yy..., dlaczego pomyślateś, że Maty Ksiażę?

U: No bo... hyy, no bo ... jak on jest na tych planetach, to opowiada jakby z pierwszej osoby.

N: Tak naprawde po co została nam opowiedziana ta historia? Czy Pilot chciat? Jakie byty zamiary, intencje opowiadacza?

$\mathrm{U}_{1}$ : To zależy..., jeżeli weźmiemy swój punkt widzenia dziecka, to to... była najciekawsza książka, a jeśli już szukamy gtębszego sensu, no to ta podróż Małego Księcia była przedstawieniem dorostości.

${ }^{18}$ D. Klus-Stańska, M. Nowicka: Sensy i bezsensy edukacji wczesnoszkolnej. Warszawa 2013, s. 98.

${ }^{19}$ Zob. ibidem, s. 99.

${ }^{20}$ Zob. ibidem, s. 104. Por. też S. Bortnow ski: Jak uczyć poezji?. Warszawa 1991, s. 8-13. 
N: Aha... Tak, że ta podróż Matego Księcia to jest właśnie istotne przedstawienie dorostości, ale jeszcze coś, tutaj jest istotne...ważnego.

$\mathrm{U}_{2}$ : To ja, chciałem pokazać sposób myślenia dzieci i pokazać, jaka jest różnica między myśleniem dziecka a myśleniem osoby dorostej.

Pytania analityczne uruchamiają myślenie krytyczne. Uczeń nie może odpowiedzieć na nie, powtarzając wyuczone fakty, wiadomości, ponieważ wymagają one analizowania informacji w celu: rozpoznania motywów i przyczyn danego zjawiska; rozważenia i przeanalizowania dostępnych informacji w celu znalezienia konkluzji czy zebrania dowodów ${ }^{21}$. Odpowiadając na tego typu pytania, uczeń uruchamia myślenie wyższego poziomu umożliwiające mu rozwiązać postawiony w pytaniu problem o charakterze otwartym, który nie ma jednego słusznego rozwiązania. Stawianie podczas lekcji tego rodzaju pytań jest szczególnie cenne, ponieważ odpowiedzi na nie dokumentują, czy uczeń potrafi myśleć logicznie, czy dostrzega związki między poszczególnymi elementami struktury problemu, czy też wykrywa nowe związki. Uczniowskie odpowiedzi na pytania analityczne znacznie częściej skłaniają nauczyciela do wejścia w rzeczywisty dialog z uczniem, w którym obie strony podtrzymują i rozwijają jedną główną linię tematyczną, np.: Maty Książę? Pilot!, Proszę bardzo yy..., dlaczego pomyślałeś, że Mały Ksiażę. Istotne jest również to, że uczniowskie odpowiedzi na pytania analityczne są nieco dłuższe w porównaniu do odpowiedzi na pytania, które wymagają jedynie przypomnienia informacji.

Pytania otwarte inicjują myślenie uczniów, pobudzają ich do ,autentycznego myślenia, odkrywania nowych szczegółów, związków między nimi wydobywania dzięki temu znaczeń tekstu"22. Zachęcają również uczniów do wymiany zdań między sobą, ponieważ otwartość pytania powoduje to, że proponowane są odmienne rozwiązania, wydawane różne opinie, co wywołuje pewien „konflikt" i chęć uzgodnienia (bądź nie) ustaleń.

Późniejsze partnerskie relacje rówieśnicze sprzyjają podejmowaniu i podtrzymywaniu dyskusji [...]. Pielęgnowanie gotowości ucznia do pozostawania $\mathrm{w}$ kontakcie werbalnym z kolegami powinno być jednym z zasadniczych i najważniejszych zadań ${ }^{23}$.

Można zatem powiedzieć, że pytania wyższego poziomu nie tylko uruchomiają złożone procesy poznawcze, ale również rozwijają kompetencję społeczną — chęć współdziałania, empatię, tolerancję, szacunek do drugiego człowieka.

${ }^{21}$ Zob. E. Perrott: Pytania..., s. 47.

${ }^{22}$ E. Nowak: Sztuka zadawania pytań. W: Doskonalenie warsztatu nauczyciela polonisty. Red. A. Janus-Sitarz. Kraków 2005, s. 143-153.

${ }^{23}$ D. Klus-Stańska, M. Nowicka: Sensy i bezsensy..., s. 106. 


\section{Nauczycielskie pytania upewniająco-instrumentalne}

Bogusław Skowronek pod pojęciem pytanie upewniajaco-instrumentalne rozumie ,akty pytajne pełniące funkcje pomocnicze podczas lekcji — instrumentalnie traktowane przez uczestników zajęć, technicznie wynikające z przebiegu lekcji”" ${ }^{24}$. Jak wcześniej wspomniałam, pełnią one funkcje pomocnicze podczas lekcji, zwykle są stawiane w celu uściślenia, doprecyzowania informacji. Od pytań merytorycznych różnią się tym, że nadawca tylko upewnia się co do zawartości informacji już posiadanej, ,jakby kierują się »wstecz «"25. Wykorzystując klasyfikację Elizabeth Perrot ${ }^{26}$, pytania upewniająco-instrumentalne można podzielić na:

1) pytania naprowadzające - stawiane przez nauczyciela, gdy uczeń daje odpowiedź a) częściowo lub całkowicie błędną; b) słabą, niepełną; c) nie wie, co odpowiedzieć; $w$ trakcie naprowadzania nauczyciel zadaje pytania dodatkowe, w których zawarte są wskazówki przybliżające treść pytania głównego;

2) pytania o wyjaśnienie - w których zwykle uczący prosi o rozbudowanie odpowiedzi, objaśnienie, uzasadnienie lub wytłumaczenie punktu widzenia; zadają je podczas lekcji przede wszystkim nauczyciele (nie należy jednak wykluczyć zadawania tego typu pytań przez uczniów) ${ }^{27}$.

W badanym materiale zgromadzono 49 pytań o charakterze upewniająco-instrumentalnym. Wykres 3. przedstawia stosunek liczbowy obu typów pytań.

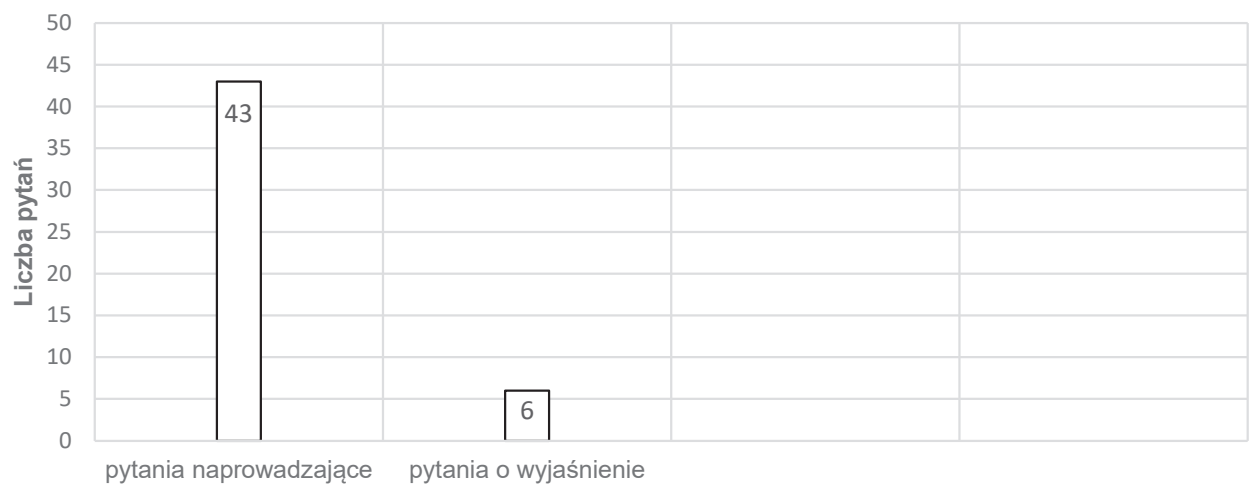

Wykres 3. Stosunek liczby pytań naprowadzających do liczby pytań o wyjaśnienie Źródło: opracowanie własne.

${ }^{24}$ B. Skowronek: O dialogu na lekcjach..., s. 60.

${ }^{25}$ Ibidem, s. 61.

${ }^{26}$ E. Perrott: Postugiwanie się pytaniami w trakcie klasowej dyskusji. W: Eadem: Efektywne nauczanie..., s. 57-88.

${ }^{27} \mathrm{~W}$ przedstawionej klasyfikacji pomijam pytania, którym Perrott nadała nazwę przesunięcia tematyczne. Uznałam, że pytania zadawane przez nauczyciela chcącego odnieść odpowiedź ucznia do innego tematu mają charakter merytoryczny. W badanym materiale nie było tego typu pytań. 
Przykład:

$\mathrm{N}$ : Od czego zaczęliśmy? Jakie byly nasze pierwsze obserwacje dotyczace tekstu?

U: Porusza...

$\mathrm{N}$ : No ale to za... zbyt ogólnie, może jeszcze coś?

U: Porusza dużo problemów.

N: Porusza dużo problemów, co jeszcze? Proszę.

Analizując przytoczone przykłady, można zauważyć, że pytania naprowadzające pojawiają się wówczas, gdy odpowiedź ucznia jest niepełna. Odnosi się jednak wrażenie, że połowiczność odpowiedzi uczniów wynika z tempa lekcji, jakie narzuciła prowadząca. Odpowiedź odbiegająca od założeń nauczycielki często jest przerywana. Na próbę repliki ucznia: Porusza... nauczycielka natychmiast reaguje: No ale to za... zbyt ogólnie, może jeszcze coś, kierując ucznia ku odpowiedzi, którą założyła. Często stawiane przez nauczycielkę pytania „naprowadzające” typu: Co jeszcze?, Jeszcze coś są nieprecyzyjne, niejasne zbyt ogólnikowe. Nie dają żadnych wskazówek pomagających uczniowi w zbudowaniu pełniejszej wypowiedzi. Jedyny komunikat zwrotny, jaki otrzymuje w ten sposób uczeń, to taki, że jego odpowiedź jest niewystarczająca bądź słaba. W innym fragmencie lekcji:

N: Tak... Coś jeszcze?... (milczenie) Dlaczego to? Dlaczego ta rozmowa, dlaczego nasza rozmowa pierwsza była rozmowa o śmierci, o przerażeniu, o lęku?

$\mathrm{U}_{2}$ : Może dlatego, że takie przerażenie...

$\mathrm{N}$ : Tak $i$ wiemy... i znamy kontekst tego dzieła polegajacego na tym, że powstato ono w czasie II wojny światowej. Co jeszcze?

$\mathrm{U}_{2}:$ Już nic.

$\mathrm{N}$ : Bo chciałeś to samo powiedzieć. No a jeszcze coś, a jeżeli odniesiemy tę informację do samej konstrukcji tekstu?

$\mathrm{U}_{3}$ : Może jakby $w$ ksiażce jest ukryty temat śmierci i pytań egzystencjalnych...

$\mathrm{N}:$ Mhm, dlatego, że jaki jest finat opowieści?

$\mathrm{U}_{3}$ : Śmierć Matego Księcia.

N: Śmierć Małego Księcia, tak! To nie jest dla nas zagadka. Dobrze.

można wskazać trzy pytania rzeczywiście naprowadzające. Po pierwszym niejasnym wyrażeniu Co jeszcze?, gdy nastaje cisza w klasie, nauczycielka daje pewne sygnały, wskazówki, które częściowo doprowadzają ucznia do lepszej, trafniejszej odpowiedzi. We wszystkich wyróżnionych pytaniach prowadząca odwołuje się do materiału, który uczeń zna: do treści poprzedniej lekcji: Dlaczego ta rozmowa, dlaczego nasza rozmowa pierwsza była rozmowa o śmierci, 
o przerażeniu, o lęku?, do budowy tekstu ${ }^{28}$ : No a jeszcze coś, a jeżeli odniesiemy tę informację do samej konstrukcji tekstu?, czy też do znajomości treści lektury: Mhm, dlatego, że jaki jest finat opowieści?.

Według Perrott, główne cele pytań naprowadzających to niesienie pomocy uczniom $\mathrm{w}$ formułowaniu odpowiedzi bardziej złożonych i przemyślanych oraz poprawa ,jakości i wielkości uczniowskiej partycypacji” ${ }^{29} \mathrm{w}$ rozmowie. Zastosowana przez polonistkę strategia polegająca na skierowaniu ucznia z powrotem, by znalazł odpowiedź na pytanie, wydaje się jednak nieskuteczna. Odpowiedzi na nieprecyzyjne pytanie Co jeszcze ${ }^{30}$ są krótkie, zaledwie kilkuwyrazowe i niepełne. Tempo lekcji, jakie narzuciła prowadząca, nie pozwala na wnikanie głębiej w błędy popełniane przez uczniów i wykorzystywanie okazji do odkrycia owych usterek, a zarazem wskazanie bardziej odpowiednich sposobów rozumowania ${ }^{31}$.

Za niepokojące zjawisko podczas naprowadzania należy uznać dążenie nauczycielki do otrzymania tej, a nie innej satysfakcjonującej ją odpowiedzi (Kto mi powie, co teraz mam na myśli?). Wówczas, jak zauważa Andrzej Janowski, pytania stają się testami mającymi sprawdzić uczniowskie umiejętność i gotowość przybliżania się do tego, co nauczyciel definiuje jako wiedzę. „Uczeń, który da się naprowadzić przez nauczyciela na właściwą - w rozumieniu nauczyciela - odpowiedź będzie oceniony jako inteligentny. Jest tak, ponieważ wiedza łączy się z władzą"32.

Brak jedynej słusznej odpowiedzi powoduje, że polonistka odpowiada sama, np.:

N: Dobrze... jaki przymiotnik... jakiego przymiotnika użyjemy w zwiazku z tym? Jaki charakter miała ta podróż?

$\mathrm{U}:$ Mmm... poznawczy.

N: Poznawczy... jeszcze jaki przymiotnik?

$\mathrm{U}$ : Naukowy.

$\mathrm{N}$ : Nooo z tym, z tą poznawczością związany?

$\mathrm{U}:$ Odkrywczy?

N: Odkrywczy, edukacyjny... Tak jest! A więc to jest taka podróż edukacyjna, a więc zobaczcie, że nasza opowieść staje się taka... yyy taka opowieściq edukacyjna [...].

${ }^{28}$ Przy założeniu, że uczeń przeczytał Małego Księcia.

29 E. Perrott: Postugiwanie się pytaniami..., s. 58.

${ }^{30}$ Podczas lekcji prowadząca zadaje ich kilkadziesiąt.

${ }^{31}$ D. Klus-Stańska: Jak nie rozwijać mowności dzieci, czyli o tzw. pogadance szkolnej. W: Edukacja polonistyczna na rozdrożach. Spotkania z językiem polskim w klasach I-III. Red. D. Klus-Stańska, M. Dagiel. Olsztyn 1999, s. 27.

32 A. Janow ski: Uczeń w teatrze życia szkolnego. Warszawa 1989, s. 172. Cyt. za: S. Bortnow ski: Przewodnik po sztuce uczenia literatury. Warszawa 2005, s. 198. 
Podczas całej lekcji prowadząca zadała 6 pytań o wyjaśnienie. Warto przy tej okazji odwołać się do ogólnopolskich badań dotyczących zadawania pytań przez nauczycieli, które zrealizowała Centralna Komisja Egzaminacyjna w 2008 roku. Badania objęły blisko 5 tysięcy uczniów i ponad 250 nauczycieli. Analizy wykazały, że pytania o wyjaśnienie zadawał co 17 nauczyciel (co w statystyce oznaczało niecałe 3 pytania na lekcji $)^{33}$.

Przykłady:

$\mathrm{N}$ : Też..., a w związku z tym użyłeś bajka, w jakim... a w jakim sensie użyteś stowa bajka jako określenie gatunku? Czy to jest ten krótki utwór wierszowany, alegoryczny prawda... bohaterami sa zwierzęta, morat itd.? Czy o tym pomyślateś?

$\mathrm{U}:$ Nie.

$\mathrm{N}$ : Nie, to o czym pomyślateś? O jakim gatunku?

$\mathrm{U}:$ O baśni...

$\mathrm{U}:$ Ten wstęp mówi o egzystencjalne...

$\mathrm{N}$ : Sensu egzystencjalnego. A co to dla Ciebie znaczy?

$\mathrm{U}$ : O lęku przed śmiercią.

$\mathrm{N}$ : O lęku przed śmiercia? Jakie znaczenie ma to [...]?

Przykłady pytań o wyjaśnienie dowodzą, że nauczycielka rzeczywiście słucha uczniów. Za pomocą tego typu pytań prowadząca pomaga swoim podopiecznym uporządkować wiadomości (np. dotyczące różnic między bajką a baśnią) czy uściślić, doprecyzować wypowiedzi (O lęku przed śmiercią? Jakie znaczenie ma to [...]). Pytania te mają charakter „współpracujący” — pozwalają odejść od schematu dialogowego opartego na krokach: inicjacja — reakcja ${ }^{34}$. Dowodzą skupienia uwagi na wspólnym celu dialogu, a uwzględnienie opinii ucznia widoczne w pytaniach nauczycielki typu: Co to dla ciebie znaczy? może świadczyć, że nauczycielka jest skłonna przyjąć inne, niż sama zakłada, ujęcie problemu. Pojawienie się tej kategorii pytań nie wpływa jednak na długość uczniowskich tekstów. W dalszym ciągu są to co najwyżej kilkuwyrazowe wypowiedzi. Może to wynikać zarówno z szybkiego tempa prowadzenia lekcji, jak i z gramatycznej konstrukcji pytań polonistki, która stawia między innymi proste pytania rozstrzygnięcia. Pytania te dają uczniom możliwość odpowiedzi jedynie tak bądź nie, np.: Czy o tym pomyślałeś?, Czy to się zaliczy do przedakcji?,

${ }^{33}$ Zob. A. Brzeziński: Lekcja pod znakiem zapytania, s. 18. https://www.nowaera.pl/o-nas/ programy-edukacyjne/ucze-i-wychowuje/motywacja/lekcja-pod-znakiem-zapytania [data dostępu: 15.03 .2020$]$.

34 Przywołuję pojęcia zaproponowane przez Urszulę Żydek-Bednarczuk, która za podstawową jednostkę rozczłonkowania rozmowy uznała krok. Zob. U. Żydek-Bednarczuk: Struktura tekstu rozmowy potocznej. Katowice 1994. 
Czy to jest ten krótki utwór wierszowany [...]? (to ostatnie ma również charakter pseudoherystyczny, ponieważ zawiera odpowiedź).

\section{Uczniowskie pytania}

„Stawianie pytań przez uczniów jest uznawane dziś za umiejętność ważniejszą aniżeli umiejętność udzielania na nie odpowiedzi. Uczeń pyta, bo podejmowane przez niego zadania są przez niego percypowane jako ważne, osobiście znaczące. Ich wykonanie wymaga konkretnych informacji” ${ }^{35}$. Uczeń zadaje pytanie, ponieważ zdobyta informacja pomoże mu wykonać zadanie. „Wobec wielości źródeł informacji, tempa przyrostu wiedzy za ważniejszą od umiejętności formułowania poprawnych odpowiedzi na zewnętrzne pytania uznawana jest dziś umiejętność ich stawiania"36. Obecność uczniowskich pytań na lekcji dowodzi, że lekcja jest dla uczniów, nie dla nauczyciela, to uczniowie muszą myśleć, mówić, działać37.

Podczas lekcji uczniowie zadali jedynie 5 pytań (zob. tabelę 1.). Obserwacja ta wpisuje się w wyniki wspomnianych już badań przeprowadzonych przez Centralną Komisję Egzaminacyjną. W publikacji Małgorzaty Żytko przedstawiającej wyniki owych badań czytamy, że w praktyce szkolnej niezwykle rzadko daje się dzieciom możliwość zadawania pytań. Pytania zwykle zadaje nauczyciel, a aktywność komunikacyjna uczniów na lekcji ogranicza się do odpowiadania na pytania nauczyciela, które nie zawsze wymagają od nich wysiłku intelektualnego ${ }^{38}$. Wprawdzie konstatacja autorki dotyczy trzecioklasistów, ale podobną można wysnuć, analizując lekcje w końcowych klasach szkoły podstawowej.

Wśród uczniowskich pytań dwa miały charakter metadydaktyczny. Ich celem było pozyskanie informacji dotyczących przebiegu lekcji i organizacji pracy. Pytania usytuowane były w ramie lekcji, czyli na jej początku i końcu.

$\mathrm{U}:$ A czyli my mamy zagadnienia, które mieliśmy... (zachowana linia intonacyjna wznosząca, pytanie przerwane przez prowadzącą);

$\mathrm{U}:$ Możemy być w trójkę?

${ }^{35}$ B.D. Gołębniak: Nauczanie i uczenie się..., s. 180.

${ }^{36}$ Ibidem.

37 S. Bortnowski: Przewodnik po sztuce..., s. 116.

${ }^{38}$ Zob. M. Ży tko: Pozwólmy dzieciom mówić i pisać - w kontekście badań umiejętności językowych trzecioklasistów, s. 97. http://biblioteka-krk.ibe.edu.pl/opac_css/doc_num.php?explnum_ id=843 [data dostępu:16.03.2020]. 
Dwa pytania były merytoryczne. Jedno z nich jest szczególnie ciekawe, ponieważ jest dowodem świadomości ucznia: pytam, bo nie wiem, a także jego zaangażowania, dzięki czemu pogadanka na krótką chwilę przeradza się w prawdziwy dialog.

U: Eee, ja mam pytania co do podróży Małego Księcia...

$\mathrm{N}$ : Proszę bardzo, co z nimi zrobimy?

U: ...no właśnie, czy to się zaliczy do przedakcji, ponieważ to się dziato przed ksiazkka, czy to będzie z kolei w trakcie akcji zaliczane jako opowieść, a nie jako jego wspomnienie z podróży...

$\mathrm{N}$ : A jak skonstruowana jest fabula? Kiedy się o tym dowiadujemy?

$\mathrm{U}$ : Eee podczas już bezpośrednio akcji.

Pytanie wyjaśniające: Dlaczego? jest interesujące ze względu na to, że zadał je uczniowi inny uczeń. To jedyna interakcja międzyuczniowska, co niewątpliwie ma związek z ,frontalnym nauczaniem" - typowym dla naszej szkoły rozwiązaniem dydaktycznym, narzucającym uczniom konieczność ciągłego skupiania się na tym, co mówi nauczyciel, nie zaś na tym, czego oczekuje kolega ${ }^{39}$.

$\mathrm{N}:[\ldots]$ Mówienie o baśni jest uprawomocnione?

$\mathrm{U}_{1}:$ Nie.

$\mathrm{N}$ : Maciek twierdzi, że nie.

$\mathrm{U}_{2}$ : Dlaczego?

$\mathrm{N}$ : No właśnie, pytanie brzmi ,dlaczego”?

Pisząc o niezadawaniu pytań przez uczniów, warto przywołać pogląd Marii Dudzik:

Uczeń w przeciętnej szkole staje się przywiązanym do ławki słuchaczem. Dziecko, podejmując naukę w szkole, natychmiast rozpoczyna wchodzić w proces blokowania jednej z naturalnych potrzeb ludzkich, jaką jest zadawanie pytań. Zamiast pogłębiania umiejętności i motywacji stawiania pytań - uczy się tego, że ich stawianie jest oznaką głupoty, złego wychowania (,,przeszkadzasz mi swymi pytaniami”, „takiej prostej rzeczy nie wiesz”), niezdyscyplinowania (,,pytasz nie na temat”) czy chęcią popisania się. To sprawia, że uczeń z czasem przestaje w ogóle pytać o cokolwiek ${ }^{40}$.

39 Zob. S. Mieszalski: Interakcje w klasie szkolnej. O społecznym funkcjonowaniu nauczycieli i uczniów w szkole podstawowej. Warszawa 1990, s. 214.

${ }^{40}$ M. Dudzikowa: Stawianie pytań stuży rozwojowi. „Nowości Oświaty” 1993, nr 5, s. 5 , za: M. Śnieżyński: Sztuka dialogu — teoretyczne założenia a szkolna rzeczywistość. Kraków 2005, s. 46. 
Warto jednak podkreślić, że podczas lekcji panowała życzliwa i przyjazna atmosfera. Nauczycielka zwracała się do uczniów po imieniu, nie manifestowała swojej pozycji, zarówno ona, jak i uczniowie przejawiali chęć uczestnictwa w rozmowie. Prowadząca dość często formułowała akty wartościowania, choć ich repertuar nie był zbyt bogaty; przykładowo: Dobrze, Tak, Tak jest. Żaden z podopiecznych nie odczuł braku akceptacji wyrażanych przez niego treści. Niesatysfakcjonująca odpowiedź ucznia była korygowana pytaniem: Co jeszcze?. Nie pojawiły się natomiast żadne akty pochwały za zadawanie przez uczniów pytań, co również mogło się przyczynić do niewielkiej ich liczby.

\section{Podsumowanie}

1. Pytania w procesie nauczania i uczenia się odgrywają ogromną rolę. Powinny służyć przede wszystkim rozwojowi ucznia. Umiejętność ich stawiania zarówno przez nauczyciela, jak i przez ucznia decyduje o tym, czy lekcja uczy myślenia - człowiek pytający to człowiek myślący ${ }^{41}$.

2. Na podstawie tego, jakie pytania stawia nauczyciel, wiemy, jakiego rodzaju rozumowania oczekuje od ucznia. W procesie kształcenia najlepiej stosować pytania niższego rzędu oraz pytania wyższego rzędu. Pierwsza grupa pytań (przypominanie, zrozumienie, zastosowanie) rozwija myślenie niżej zorganizowane i jest ściśle związana z rolą nauczyciela. Służy sprawdzaniu wiedzy i rozpoznaniu ewentualnych jej braków. Drugi typ pytań rozwija myślenie wyżej zorganizowane. Do tej grupy należą pytania aktywizujące ucznia, pobudzające zainteresowanie podejmowanym zagadnieniem. Pytania te przyczyniają się do formułowania własnych rozważań, wniosków opartych na wcześniejszych analizach. Często pobudzają do dyskusji, która umożliwia rozwiązanie postawionego w pytaniu problemu ${ }^{42}$. Podczas analizowanej lekcji zadawano przede wszystkim pytania rozwijające myślenie niżej zorganizowane, których zadaniem jest sprawdzanie szkolnej wiedzy i rozpoznanie ewentualnych jej braków. Tylko co czwarte pytanie to pytanie rozwijające myślenie wyżej zorganizowane — służące rozbudzaniu ciekawości poznawczej, rozwijaniu krytycyzmu, wspierające samodzielność i kreatywność ucznia.

3. Wyniki przeprowadzonych badań pozwalają stwierdzić, że znacznie częściej powinny padać właściwe pytania o wyjaśnienie, które skłaniają ucznia do dłuższej wypowiedzi, bardziej przemyślanej i uporządkowanej. Dzięki

\footnotetext{
${ }^{41}$ E. Nowak: Sztuka zadawania..., s. 144.

${ }^{42}$ R. Fisher: Uczymy jak się uczyć. Tłum. K. Kruszewski. Warszawa 1999.
} 
pytaniom o wyjaśnienie z góry określona linia tematyczna (już w fazie planowania lekcji wiadomo, jakie pytania zostaną postawione oraz jakie odpowiedzi powinny zostać udzielone) ${ }^{43}$ „łamie” się — dochodzi do autentycznej rozmowy.

4. Badanie pokazało, że uczniowie niezwykle rzadko zadają pytania nauczycielowi, a jeszcze rzadziej innym uczniom. A to właśnie umiejętność zadawania pytań powinna być rozwijana w szkole. Stawianie pytań świadczy bowiem o otwartości ucznia, gotowości odkrywania „,nowych prawd”, a przede wszystkim uświadamia mu jego własną niewiedzę. Dodatkowo zadawanie przez ucznia pytań nie było gratyfikowane w formie na przykład ustnej pochwały czy innego zabiegu dowartościowującego.

5. Główną aktywnością uczniów jest odpowiadanie na pytania. Zwraca również uwagę znaczna dysproporcja udziału w rozmowie: nadawcą komunikatu lekcyjnego jest przede wszystkim nauczycielka, której teksty zarówno pod względem długości, jak i złożoności znacznie różniły się od krótkich i odtwórczych wypowiedzi uczniów.

6. Wydaje się, że największym „wrogiem” nauczycielki i uczniów jest przymus realizacji z góry określonych celów zawartych w temacie (Konstrukcja fabuły „Małego Księcia” i jej znaczenie), a także brak czasu. Konieczność realizacji ściśle opracowanych treści programowych, na które przeznaczona jest jedna lekcja, powoduje, że najefektywniejszą metodą prowadzenia zajęć staje się pogadanka, której antyrozwojowy charakter wiąże się z „odgórną selekcją i narzucaniem znaczeń oraz nadawaniem im charakteru reproduktywnego" ${ }^{\prime 44}$. $\mathrm{Na}$ koniec warto przytoczyć wciąż aktualną (acz smutną) obserwację Stanisława Bortnowskiego:

Prawie wszystkie lekcje z literatury w liceach bądź w technikach prowadzone są metodą pogadanki heurystycznej. Nauczyciel sam formułuje temat lekcji, sam stawia pytania, pytań tych jest bardzo dużo, są to raczej pytania szczegółowe, czyli wymagające odpowiedzi krótkiej, jedno- lub kilkuzdaniowej. Uczniowie na te pytania udzielają (z trudem lub bez trudu) takich właśnie króciutkich odpowiedzi, otrzymują kolejne pytania i odpowiadają na podstawie tzw. tropienia pamięci, czyli przypominania rzeczy znanych, kojarzenia, wnioskowania ${ }^{45}$.

${ }^{43}$ Zob. J. Nocoń: Stylistyczne aspekty dyskursu edukacyjnego. W: Odmiany stylowe polszczyzny - dawniej i dziś. Red. U. Sokólska. Białystok 2011, s. 196.

${ }^{44}$ D. Klus-Stańska, M. Nowicka: Sensy i bezsensy..., s. 104.

${ }^{45}$ S. Bortnowski: Jak uczyć..., s. 10. 


\section{Bibliografia}

Barnes D.: Nauczyciel i uczniowie. Od porozumiewania się do ksztatcenia. Tłum. J. Radzicki. Warszawa 1988.

Biłos E.: Wypowiedzenia pytajne w nauczaniu języka polskiego. Częstochowa 1992.

Bortnowski S.: Jak uczyć poezji?. Warszawa 1991.

Bortnowski S.: Przewodnik po sztuce uczenia literatury. Warszawa 2005.

Dudzikowa M.: Stawianie pytań stuży rozwojowi. „Nowości Oświaty” 1993, nr 5.

Fisher R.: Uczymy jak się uczyć. Tłum. K. Kruszewski. Warszawa 1999.

Gołębniak B.D.: Nauczanie i uczenie się w klasie. W: Pedagogika 2: Podręcznik akademicki. Red. Z. Kwieciński, B. Śliwerski. Warszawa 2014.

Kawka M.: Dyskurs szkolny. Zagadnienia języka. Kraków 1999.

Klus-Stańska D.: Jak nie rozwijać mowności dzieci, czyli o tzw. pogadance szkolnej. W: Edukacja polonistyczna na rozdrożach. Spotkania z językiem polskim w klasach I-III. Red. D. Klus-Stańska, M. Dagiel. Olsztyn 1999.

Klus-Stańska D., Nowicka M.: Sensy i bezsensy edukacji wczesnoszkolnej. Warszawa 2013.

Kojs W.: Pytania i polecenia w kształceniu systematycznym. Analiza operatorów. Katowice 1994.

Kojs W.: Uwarunkowania dydaktycznych funkcji podręcznika. Warszawa 1975.

Mieszalski S.: Interakcje w klasie szkolnej. O społecznym funkcjonowaniu nauczycieli i uczniów w szkole podstawowej. Warszawa 1990.

Myrdzik B.: Czy rozmowa jest metoda?. W: Eadem: Nowoczesność i tradycja w ksztatceniu literackim. Podręcznik do ćwiczeń z metodyki języka polskiego. Lublin 2000.

Nocoń J.: Polecenia i pytania w podręcznikach nauki o języku. Opole 1997.

Nocoń J.: Stylistyczne aspekty dyskursu edukacyjnego. W: Odmiany stylowe polszczyzny — dawniej i dziś. Red. U. Sokólska. Białystok 2011.

Nowak E.: Sztuka zadawania pytań. W: Doskonalenie warsztatu nauczyciela polonisty. Red. A. Janus-Sitarz. Kraków 2005.

Perrott E.: Postugiwanie się pytaniami w trakcie klasowej dyskusji. W: Eadem: Efektywne nauczanie. Praktyczny przewodnik doskonalenia nauczyciela. Tłum. A. Janowski. Warszawa 1995, s. $57-88$.

Perrott E.: Pytania. W: Eadem: Efektywne nauczanie. Praktyczny przewodnik doskonalenia nauczyciela. Tłum. A. Janowski. Warszawa 1995, s. 44-56.

Putkiewicz E.: Proces komunikowania się na lekcji. Analiza wypowiedzi nauczycieli i uczniów. Warszawa 1990.

Skowronek B.: O dialogu na lekcjach w szkole średniej. Analiza pragmatyczno-językowa. Kraków 1999.

Stake R.E.: Studium przypadku. W: Ewaluacja w edukacji. Red. L. Korporowicz. Warszawa 1997.

Śnieżyński M.: Sztuka dialogu — teoretyczne założenia a szkolna rzeczywistość. Kraków 2005.

Tabisz A.: Czy lekcje języka polskiego ucza myślenia?. „Polonistyka. Innowacje” [w druku].

Tabisz A.: O pytaniach podczas rozmowy maturalnej z języka polskiego. „Kształcenie Językowe” 2019, nr 17, s. 29-41.

Żydek-Bednarczuk U.: Struktura tekstu rozmowy potocznej. Katowice 1994. 


\section{Źródła internetowe}

Brzeziński A.: Lekcja pod znakiem zapytania. https://www.nowaera.pl/o-nas/programy-eduka cyjne/ucze-i-wychowuje/motywacja/lekcja-pod-znakiem-zapytania [data dostępu: 15.03.2020].

Mizerek H.: Studium przypadku w badaniach nad edukacja. Istota i paleta zastosowań. https:// repozytorium.ukw.edu.pl/bitstream/handle/item/5517/Studium $\% 20$ przypadku $\% 20 \mathrm{w} \% 20$ badaniach $\% 20$ nad $\% 20$ edukacj\%c4\%85\%20Istota\%20i\%20paleta $\% 20$ zastosowa $\%$ c5\% 84 . pdf?sequence $=1 \&$ isAllowed=y [data dostępu: 15.03.2020].

Żytko M.: Pozwólmy dzieciom mówić i pisać - w kontekście badań umiejętności językowych trzecioklasistów. http://biblioteka-krk.ibe.edu.pl/opac_css/doc_num.php?explnum_id=843 [data dostępu: 16.03.2020]. 